\begin{tabular}{|l|l|}
\hline 2. To: (Receiving Organization) & 3. From: (Originating Orgenization) \\
Packaging Engineering & Packaging Engineering \\
\hline 5. Proj./Prog./Dept./Div.: & 6. Design Authority/ Dosion Agent/Cog. \\
03 E00 & J. S. Boettger \\
\hline
\end{tabular}

8. Originator Remarks:

This safety evaluation for packaging is being submitted for approval and release.
11. Receiver Remerks:
11A. Design Basel ine Document?
[] Yes [x] No

4. Reloted EOT No.:
621077
7. Purchase Order No.:
N/A

9. Equip./Component Mo.:

$N / A$

10. Syzten/Bldg./facflity: N/A

12. Major Assm. Dwg. No.: $N / A$

13. Permit/Permit Application No.: $N / A$

14. Requi red Response Date: N/A

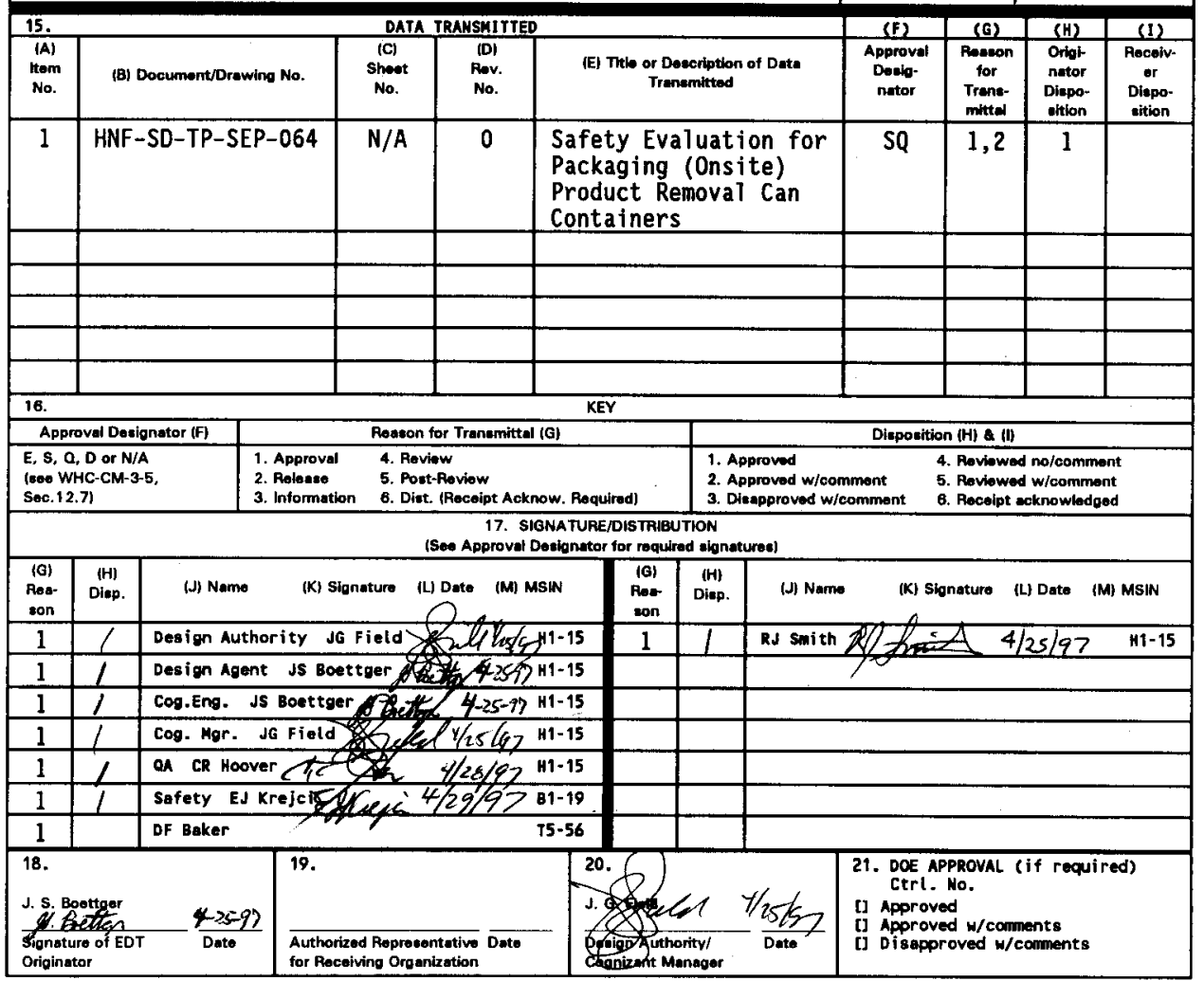

BD-7400-172-2 (05/96) GEF097 


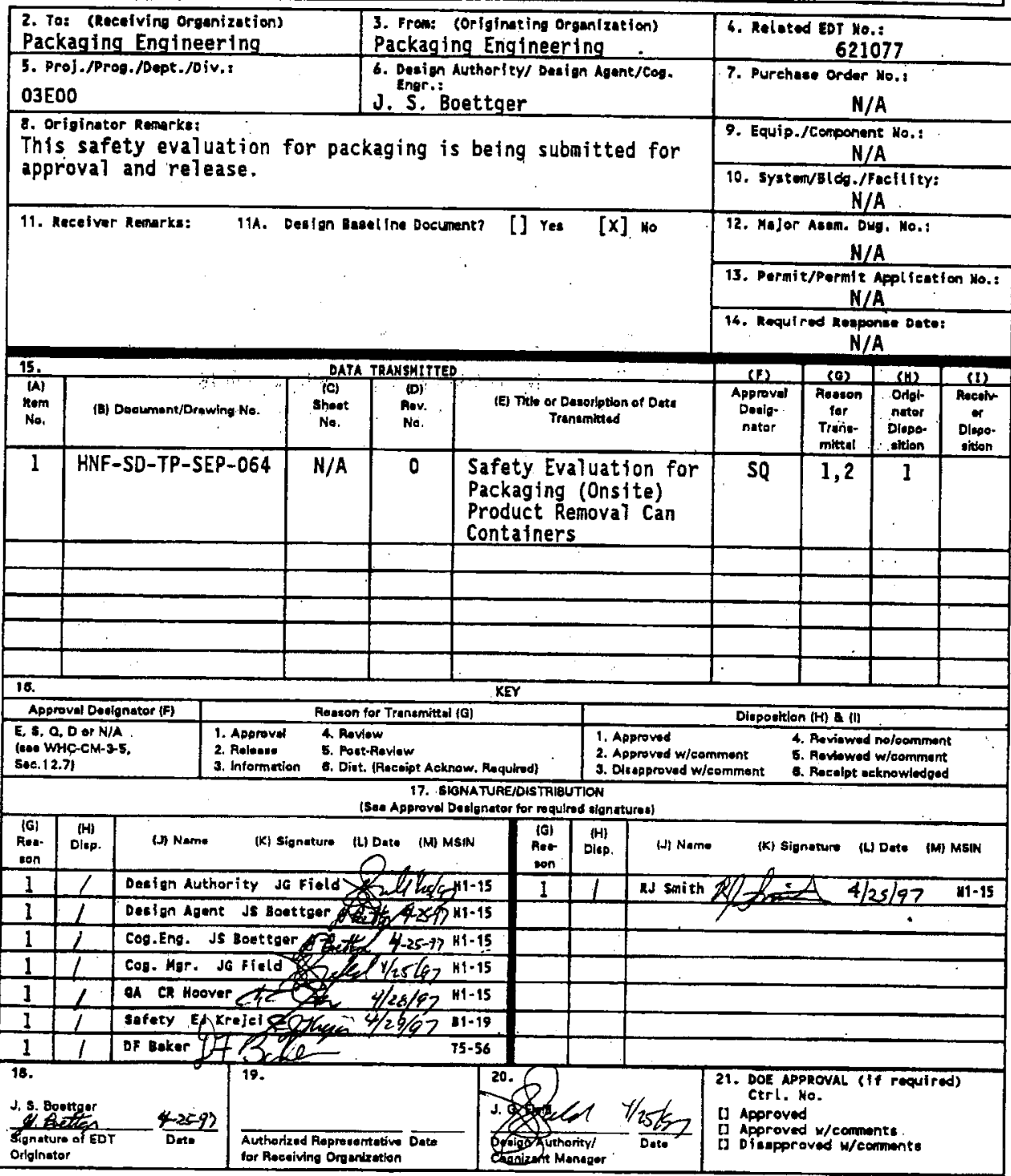




\section{Safety Evaluation for Packaging (Onsite) Product Removal Can Containers}

\section{J. S. Boettger}

Rust Federal Services Inc. Northwest Operations, Richland, WA 99352

U.S. Department of Energy Contract DE-AC06-96RL13200

$\begin{array}{llll}\text { EDT/ECN: } & 621078 & \text { UC: } 513 & \\ \text { Org Code: } & 03 E 00 & \text { Charge Code: } & \text { KP526 } \\ \text { B\&R Code: } & \text { EW7050000 } & \text { Total Pages: } & 9\end{array}$

Key Words: transport, PR Can, PUREX, Plutonium Finishing Plant

Abstract: This safety evaluation for packaging allows the transport of nine Product Removal (PR) Cans with their Containers from the PUREX Facility to the Plutonium Finishing Plant.

TRADEMARK DISCLAIMER. Reference herein to any specific conmercial product, process, or service by trade name, tradenark, manufacturer, or otherwise, does not necessarily constitute or imply its endorsement, recommendation, or favoring by the United States Government or any sgency thereof or its contractors or subcontractors.

Printed in the United States of America. To obtain copies of this document, contact: WHC/BCS Document Control Services, P.0. Box 1970, Mailstop H6-08, Richland WA 99352, Phone (509) 372-2420; Fax (509) 376-4989.

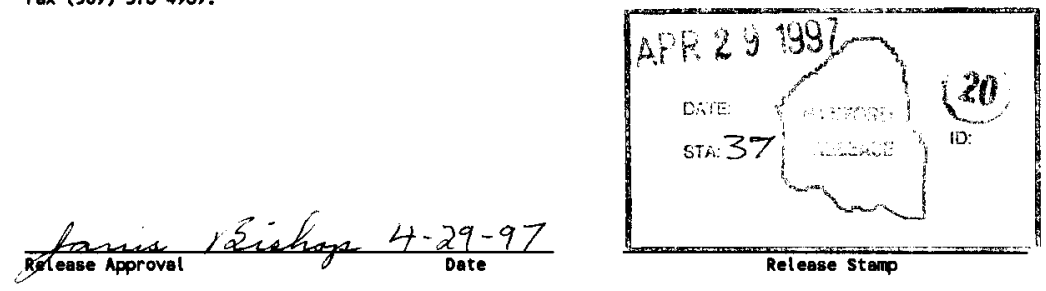


HNF-SD-TP-SEP-064, Rev. 0

\section{CONTENTS}

1.0 GENERAL INFORMATION $\ldots \ldots \ldots \ldots \ldots$

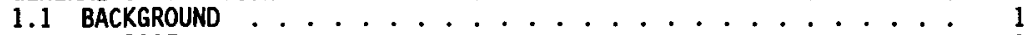

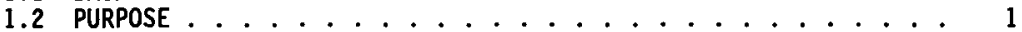

2.0 PACKAGING DESCRIPTION . . . . . . . . . . . . 1

2.1 EMERGENCY PR CAN PACKAGE ................. 1

2.2 STANDARD PR CAN PACKAGE $\ldots \ldots \ldots \ldots$

2.3 MARK IV AND MARK $\checkmark$ PR CAN PACKAGE ............ 2

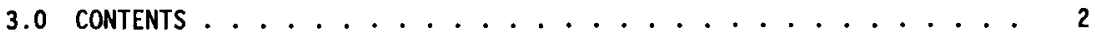

4.0 BASIS OF SAFETY ...................... 3

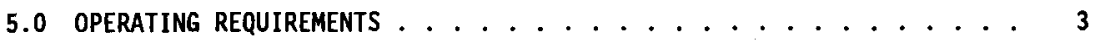

6.0 REFERENCES ........................... 6

FIGURE

5-1 Tiedown System ..................... 5

TABLE

3-1 Maximum Source Term ................ 2 
HNF-SD-TP-SEP-064, Rev. 0

\section{LIST OF TERMS}

$\begin{array}{ll}\mathrm{Ci} & \text { curie } \\ \mathrm{cm} & \text { centimeter } \\ \mathrm{dpm} / \mathrm{cm}^{2} & \text { disintegrations per minute per square centimeter } \\ \mathrm{ft} \cdot 1 \mathrm{~b} & \text { foot-pound } \\ \mathrm{in} . & \text { inch } \\ \mathrm{kg} & \text { kilogram } \\ \mathrm{km} & \text { kilometer } \\ \mathrm{lb} & \text { pound } \\ \mathrm{mi} & \text { mile } \\ \mathrm{N} \cdot \mathrm{m} & \text { newton meter } \\ \text { PR } & \text { Product Removal } \\ \text { PUREX } & \text { Plutonium-Uranium Extraction (Facility) } \\ \text { SARP } & \text { Safety Analysis Report for Packaging } \\ \text { wt\% } & \text { weight percent }\end{array}$




\section{SAFETY EVALUATION FOR PACKAGING (ONSITE) PRODUCT REMOVAL CAN CONTAINERS}

\subsection{GENERAL INFORNATION}

\subsection{BACKGROUND}

Nine Product Removal (PR) Cans and Containers are located within the Plutonium-Uranium Extraction (PUREX) Facility. Each can is expected to contain a maximum of $3 \mathrm{~g}$ of residual radioactive material, consisting mainly of plutonium isotopes.

The PR Can Containers were previously authorized by Safety Analysis Report for Packaging (SARP) SD-RE-SAP-070 (Nelson-Jensen 1986) for the interarea transport of up to $10 \mathrm{~g}$ of plutonium. The SARP was canceled in 1993 because no further use for the container was foreseen.

\subsection{PURPOSE}

The purpose of this safety evaluation for packaging is to allow the transport of nine PR Cans with their Containers from the PUREX Facility to the Plutonium Finishing Plant.

\subsection{PACKAGING DESCRIPTION}

The PR Can Package is defined as the PR Can inside the PR Can Container.

\subsection{EMERgENCY PR CAN PACKAgE}

The Emergency PR Can, Drawing H-2-58129, is constructed of 6-in. Schedule 80 stainless steel pipe $68.6 \mathrm{~cm}$ (27.0 in.) in length. The can is identified by numbers stamped directly under the lifting lug. Identification numbers begin with the number E301 and continue consecutively through E605.

The Emergency PR Can Container, Drawing $\mathrm{H}-2-58130$, is $58.4 \mathrm{~cm}$ (23.0 in.) in diameter and $105 \mathrm{~cm}$ (41.5 in.) high. A more detailed description of the package is contained in the safety analysis report for packaging (NelsonJensen 1986).

\subsection{STANDARD PR CAN PACKAGE}

The Standard PR Can, Drawing H-2-52967, is constructed of 6-in. Schedule 80 S stainless steel pipe that is $52.1 \mathrm{~cm}(20.5 \mathrm{in.})$ in length. The can is marked by identification numbers $1.27 \mathrm{~cm}(0.50 \mathrm{in}$.$) high stamped on the$ lifting trunnion. 
The Standard PR Can Container, Drawing H-2-52984, is constructed of $0.64-\mathrm{cm}(0.25-i n$.$) carbon steel, 55.9 \mathrm{~cm}(22.0 \mathrm{in.})$ in diameter and $81.3 \mathrm{~cm}$ (32.0 in.) in height. The container is identified by numbers $2.54 \mathrm{~cm}$ ( $1.00 \mathrm{in.}$ ) wide and $15.2 \mathrm{~cm}(6.00 \mathrm{in}$.$) high on the side of the container and$ on the lid of the container. A more detailed description of the package is contained in the SARP (Nelson-Jensen 1986).

\subsection{MARK IV AND MARK V PR CAN PACKAGE}

The Mark IV PR Can, Drawing H-2-26417, is constructed of 6-in. Schedule $40 S$ pipe stainless steel and is $80.0 \mathrm{~cm}$ (31.5 in.) in overall length. The Mark V PR Can is identical except for being constructed of Schedule $80 S$ pipe. When in transport, the PR Can is placed in the PR Container that is $58.4 \mathrm{~cm}$ (23.0 in.) in diameter and $105 \mathrm{~cm}$ (41.5 in.) in height. The Mark IV and Mark V PR Cans are stamped with numbers $0.64 \mathrm{~cm}(0.25 \mathrm{in}$.) high on the end of the 1 ifting trunnions. Mark IV identification numbers begin with 701 . Mark V identification numbers begin with 901 . A more detailed description of the package is contained in the SARP (Nelson-Jensen 1986).

\subsection{CONTENTS}

Each PR Can contains no more than $3 \mathrm{~g}$ of radioactive material. The maximum source term, assuming $12 \%{ }^{240} \mathrm{Pu}$, is shown in Table 3-1.

Table 3-1. Maximum Source Term.

\begin{tabular}{|l|c|c|}
\hline Isotope & Wt\% & Total activity (Ci) \\
\hline${ }^{238} \mathrm{Pu}$ & $0.1090 \%$ & $5.6 \mathrm{E}-02$ \\
\hline${ }^{239} \mathrm{Pu}$ & $85.3100 \%$ & $1.6 \mathrm{E}-01$ \\
\hline${ }^{240} \mathrm{Pu}$ & $12.0650 \%$ & $8.3 \mathrm{E}-02$ \\
\hline${ }^{241} \mathrm{Pu}$ & $2.2200 \%$ & $6.7 \mathrm{E}+00$ \\
\hline${ }^{242} \mathrm{Pu}$ & $0.3035 \%$ & $3.6 \mathrm{E}-05$ \\
\hline${ }^{241} \mathrm{Am}$ & $0.1407 \%$ & $1.4 \mathrm{E}-02$ \\
\hline Total & -- & $7.0 \mathrm{E}+00$ \\
\hline
\end{tabular}

The effective $A_{2}$ value for this mixture of radionuclides is $0.0848 \mathrm{C}$, the total activity is $7.0 \mathrm{Ci}$. Therefore, the contents are Type $B$, fissile excepted. 


\subsection{BASIS OF SAFETY}

The safety of this shipment is based on the following.

1. The PR Can Container was previously evaluated and authorized for interarea shipments of up to $10 \mathrm{~g}$ of plutonium. This safety evaluation for packaging will only authorize $3 \mathrm{~g}$ of plutonium.

2. The interarea shipment will be one time, for a distance of approximately $16.1 \mathrm{~km}$ (10.0 mi).

3. Operating controls of Section 5.0, based on the original SARP (Nelson-Jensen 1986), will provide an additional level of safety.

4. This safety evaluation for packaging will be canceled after the shipment or one year after release, whichever comes first.

\subsection{OPERATING REQUIREMENTS}

1. Ensure all applicable instructions and procedures for onsite shipment of radioactive material comply with WHC-CM-2-14, Hazardous Material Packaging and Shipping.

2. The external surface of the PR Cans and PR Containers shall be inspected for structural defects or evidence of leakage before moving.

3. The residual material in the PR Can Packages shall not exceed $3 \mathrm{~g}$ of plutonium.

4. Emergency and Standard PR Cans shall be fitted with the modified 1id, Drawing $\mathrm{H}-2-95644$, and torqued to $44.3 \pm 3.70 \mathrm{~N} \cdot \mathrm{m}$ $(60.0 \pm 5.00 \mathrm{ft} \cdot 1 \mathrm{~b})$.

5. A \#14 snug-fitting, rubber stopper, Drawings H-2-26417, H-2-95644, and H-2-95926, shall be placed on the Emergency, Mark IV, and Mark V PR Can lid hex head bolts prior to shipping.

6. Mark IV and Mark V PR Can lid bolts shall be tightened snug with a hand-held wrench while ensuring all components come into proper contact. When the components are snug, an additional $1 / 2$ turn (1/3 minimum to $2 / 3$ maximum) shall be applied.

7. A gasket shall be in place on all PR Container lids.

8. Emergency, Mark IV, and Mark V PR Container lids shall be tapped with a mallet while torquing the bolt to $29.5 \pm 3.00 \mathrm{~N} \cdot \mathrm{m}$ $(40.0 \pm 4.00 \mathrm{ft} \cdot 1 \mathrm{~b})$. Lever type closure rings shall not be used. 
9. The outside of the PR Can Packages shall be surveyed prior to shipment. The outside of the PR Container shall have less than $2.2 \mathrm{dpm} / \mathrm{cm}^{2}$ alpha and less than $22 \mathrm{dpm} / \mathrm{cm}^{2}$ beta-gamma smearable contamination.

10. Radiation dose rates at the surface of the package shall not exceed background levels.

11. The outer container must be sealed with a security seal, which is not readily breakable and, while intact, would be evidence that the package has not been opened by unauthorized persons.

12. The allowable gross vehicle weight 1 imit shall not be exceeded.

13. The PR Can Packages shall be secured on the transport vehicle in accordance with Figure 5-1. The PR Can Packages shall be transported in a closed transport vehicle.

14. No more than 12 PR Can Packages, of which 3 can be Standard, shall be shipped on a struck at one time.

15. Standard PR Can Packages are to be shipped in the front row only (row nearest the cab of the truck) with any combination of PR Can Packages behind, in rows of three.

16. Each row of three containers is to be tightly strapped to the side of the truck. Two straps per row are to be used, with each strap having a minimum manufacturer's rated capacity of $1134 \mathrm{~kg}$ (2500 $\mathrm{lb}$ ).

17. One Ancra ${ }^{1}$ bar shall be placed over each row, except for the Standard PR Can Package row, which shall have two Ancra bars placed across it. Ancra bars shall be within $7.62 \mathrm{~cm}(3.00 \mathrm{in}$.$) of the top$ of the containers.

18. Two Ancra bars shall be installed behind the container array, as close as possible to the rear row.

19. The route to be traveled shall be free of driving hazards, such as road repair or construction activities, that would endanger the safe transport of the shipment.

20. One operator is required to ride in the transport vehicle with the driver.

21. The speed of the transport vehicle shall be in compliance with the posted speed limits.

22. In an accident situation, one of the first recovery steps shall be to upright the container if necessary. 
HNF-SD-TP-SEP-064, Rev. 0

Figure 5-1. Tiedown System.

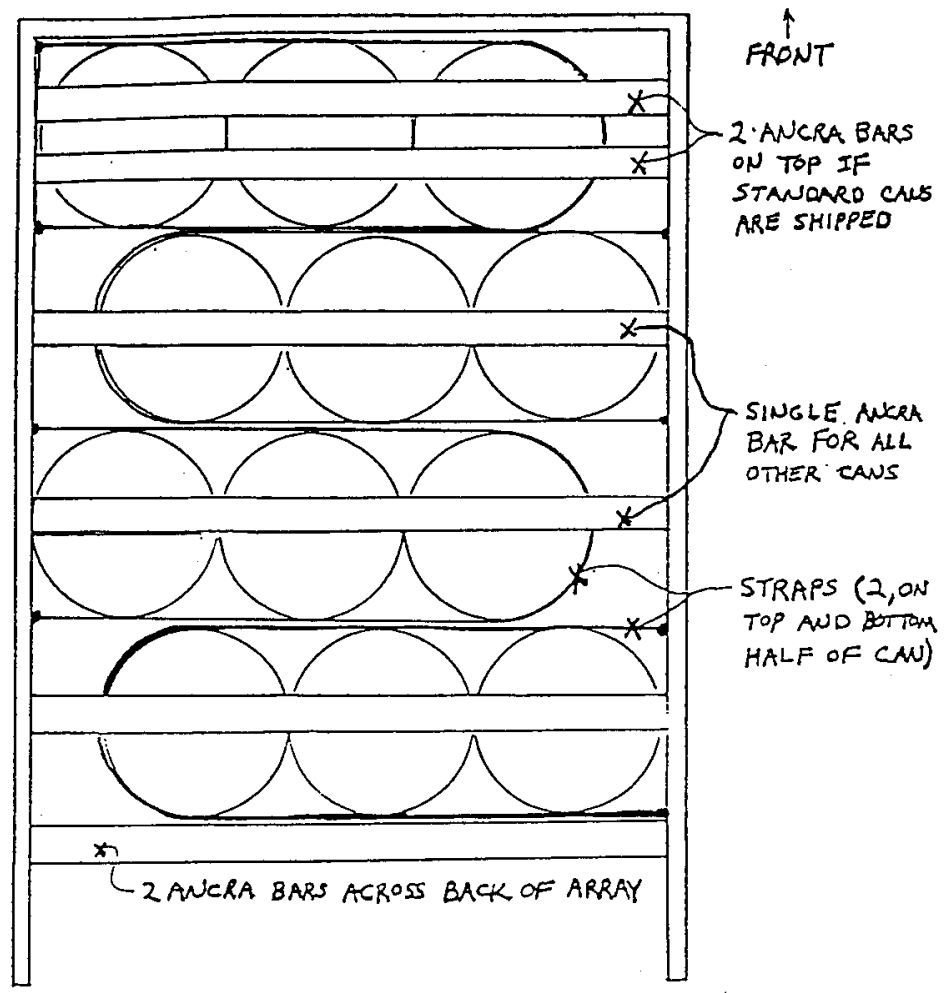

For above exaryle: 7 ANCRA Bars and 8 strogs are reguired. 
HNF-SD-TP-SEP-064, Rev. 0

\subsection{REFERENCES}

Nelson-Jensen, K., 1986, SD-RE-SAP-070, Rev. 2, Safety Analysis Report for Packaging, Interarea Transport of Unloaded $P R$ Cans and Containers, SD-RE-SAP-070, Rev. 2, Rockwell Hanford Company, Richland, Washington (canceled 1993, Rev. 3, Westinghouse Hanford Company, Richland, Washington).

WHC-CM-2-14, Hazardous Material Packaging and Shipping, Westinghouse Hanford Company, Richland, Washington. 


\begin{tabular}{|c|c|c|c|c|c|}
\hline \multicolumn{6}{|c|}{ DISTRIBUTION SHEET } \\
\hline To & \multirow{2}{*}{\multicolumn{3}{|c|}{$\begin{array}{l}\text { From } \\
\text { Packaging Engineering }\end{array}$}} & \multicolumn{2}{|l|}{ Page 1 of 1} \\
\hline Distribution & & & & \multicolumn{2}{|c|}{ Date Apr. 29, 1997} \\
\hline \multicolumn{4}{|c|}{ Project Title/Work Order } & \multicolumn{2}{|c|}{ EDT No. 621078} \\
\hline \multicolumn{4}{|c|}{$\begin{array}{l}\text { Safety Evaluation for Packaging (Onsite) Product Removal Can } \\
\text { Containers (HNF-SD-TP-SEP-064, Rev. 0) }\end{array}$} & \multicolumn{2}{|l|}{ ECN No. N/A } \\
\hline Name & MSIN & $\begin{array}{l}\text { Text } \\
\text { With All } \\
\text { Attach. }\end{array}$ & Text Only & $\begin{array}{l}\text { Attach./ } \\
\text { Appendix } \\
\text { Only }\end{array}$ & $\begin{array}{l}\text { EDT/ECN } \\
\text { Only }\end{array}$ \\
\hline $\begin{array}{l}\text { D. F. Baker } \\
\text { J. S. Boettger } \\
\text { J. G. Field } \\
\text { C. R. Hoover } \\
\text { E. J. Krecji } \\
\text { R. J. Smith } \\
\text { Central Files }\end{array}$ & $\begin{array}{l}T 5-56 \\
H 1-15 \\
H 1-15 \\
H 1-15 \\
B 1-19 \\
H 1-15 \\
A 3-88\end{array}$ & $\begin{array}{l}x \\
x \\
x \\
x \\
x \\
x \\
x\end{array}$ & & & \\
\hline HNF-SD-TP-SEP-064 File & $H 1-15$ & $x$ & & & \\
\hline
\end{tabular}

